\title{
The Implementation of Basic Principles of Financial Management to Improve Higher Education Reputation
}

\author{
Agustinus Purna Irawan ${ }^{1,2^{*}}$ Eddy Supriyatna ${ }^{1}$ Indra Widjaja ${ }^{1}$ Linda Lin-Chin Lin ${ }^{3}$
}

\author{
${ }^{1}$ Master of Management, Universitas Tarumanagara, Jakarta, Indonesia \\ ${ }^{2}$ Faculty of Engineering, Universitas Tarumanagara, Jakarta, Indonesia \\ ${ }^{3}$ Department of Business Administration, Kun Shan University, Tainan 710303, Taiwan \\ *Corresponding author.Email: agustinus@untar.ac.id
}

\begin{abstract}
The development of higher education in Indonesia, especially private universities, is very dependent on the ability to obtain funding sources and manage them so that they can meet financial needs and various other needs. The main source of funding for private universities is tuition fees charged to students and supported by other sources of income such as research grants, further study grants, university management grants, donations from various institutions in the form of scholarships, donations, and the results of expertise services in the form of training, seminars, researches, laboratory activities and several other activities. So important is the management of funds in private universities to carry out the activities of The Threefold Missions of Higher Education (Tri Dharma Perguruan Tinggi) and the sustainability of the program, a good financial management system is needed. In general, there are 10 principles that must be considered in financial management. This paper discusses good and sustainable financial management strategies for private universities by referring to the 10 principles of financial management and other operational supporting regulations. The method of discussion uses descriptive methods accompanied by examples of cases and analysis. Based on the discussion that has been done, the results show that innovation and creativity in the financial management of private universities can improve the reputation, performance, and sustainability of higher education. This result will be one of the references in the next development.
\end{abstract}

Keywords: financial management, private university, good governance university, reputation

\section{INTRODUCTION}

One of the current managements of higher education institutions in Indonesia refers to the National Higher Education Standards, in accordance with Permendikbud No. 3 of 2020. Referring to article 3 paragraph 1 , Permendikbud No. 3 of 2020, "the goal of the national higher education standard is to ensure the achievement of the goals of higher education which play a strategic role in educating the nation's life, advancing science and technology by applying humanities values as well as the sustainable culture and empowerment of the Indonesian people; ensure that the quality of the Learning in Study, Research and Community Service Programs organized by Tertiary Education Institutions throughout the jurisdiction of the Republic of Indonesia reaches the quality according to the criteria set out in the National Higher Education Standards; and encouraging higher education institutions in all jurisdictions of the Republic of Indonesia to achieve the quality of learning, research, and community service beyond the criteria set out in the National Higher Education Standards in a sustainable manner "(Permendikbud No. 3 of 2020) [1].
One of the important things that can support the achievement of higher education management goals according to national standards is the availability of the funds needed and good financial management. Finance in every organization, both companies and educational institutions, is an important foundation so that it can carry out its operations properly according to the objectives of the organization. Good and accountable financial management is needed to support the performance of the entire system in the organization. Therefore, modern financial management needs to be applied in higher education, so that it can carry out the activities of the Threefold Missions of Higher Education with quality and gain the trust of the wider community [2-9].

Financial management is an activity of planning, managing, storing, controlling funds and assets owned by an institution, including universities. Financial Management is an essential part of the economic and non-economic activities which leads to decide the efficient procurement and utilization of finance with profitable manner. Financial management is one of the important parts of overall management, which is directly related with various functional departments like personnel, marketing, and production [10]. In general, the goal of financial 
management is to get a good profile so that it leads to an organization that has good wealth to carry out organizational activities (Figure 1).

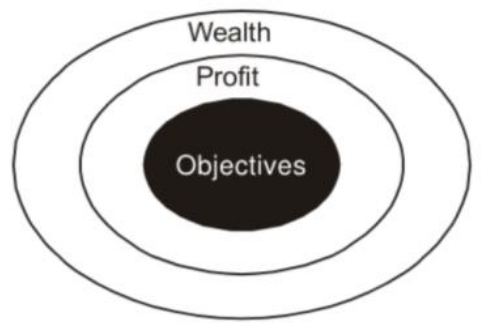

Figure 1. The objectives of financial management [10]

Financial management is the process of managing finances by considering the effectiveness and efficiency aspects related to the acquisition, funding, and management of assets, starting from planning, organizing, implementing, to monitoring. School financial management is a process of activities that are planned and carried out deliberately and seriously, as well as continuous guidance on school operational costs so that educational activities are more effective and efficient and help achieve educational goals [46]. Educational finance, an important factor in the success in educational practices, is an analysis of revenue and expenditure used to effectively and efficiently manage education to achieve the goals that have been determined [5-9].

In general, there are 10 principles of financial management that must be considered in financial management, as follows: the risk-return trade off, time value of money, cashnot profit-is king, incremental cash flows, the curse of competitive market, efficient capital market, the agency problem, taxes bias business decisions, all risk is not equal, and ethical dilemmas are everywhere in finance. Financial management must be carried out properly so that it does not cause problems at present and in the future, by referring to the 10 principles of financial management and other operational supporting regulations. Financial and asset management must also consider future funding needs by preparing an endowment fund, so that universities can continue to carry out higher quality and reputable higher education services both at home and abroad. For example, US higher education has essentially the same financial model for 150 years. Tuition, taxpayer funding, and donations/grants provide revenues. Recently, however, the model has become increasingly challenged [11-15].

In the face of pressing financial and technology forces for change, not-for-profit higher education institutions need to move from long-successful financial and curriculum models to new models that fit the vastly different conditions of the $21^{\text {st }}$ century. Even among those most vested in the status quo, the expectation is that the future will be very different than today and will arrive soon [11-15].

The use of funds at a private university must be well managed and reports on its use must be prepared so that it can be verified and audited by internal and external parties. Paramasivan, 2009 [10] presented a model of financial statement analysis techniques that can be used as a reference in corporate financial management, including private universities. This model divides the analysis into several parts, making it easier to prepare and analyses financial reports.

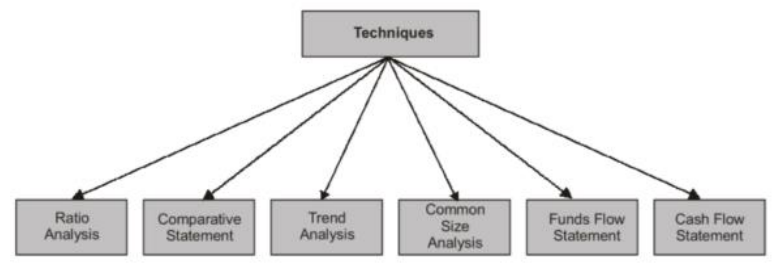

Figure 2. The techniques of financial statement analysis [10]

This paper discusses how financial management by applying the basic principles of financial management, especially in private universities, can improve performance and reputation within the community and all other stakeholders. The discussion in this paper is focused on how to manage finances and find sources of funding needed by private universities, by applying the basic principles of financial management. In this case, money is not everything, but the reputation built by private tertiary institutions requires financing that needs to be managed independently through various sources of financing in accordance with the activities carried out.

\section{METHOD}

Discussions related to the implementation of the basic principles of financial management in building the reputation of higher education institutions, especially private universities, are carried out with descriptive and analytical methods based on various references, financial regulations, higher education accreditation regulations, and experiences in university financial management practices that have been implemented so far. Several case studies are discussed in this paper to support the discussion regarding the implementation of the basic principles of financial management in building the reputation of private universities (Figure 3).

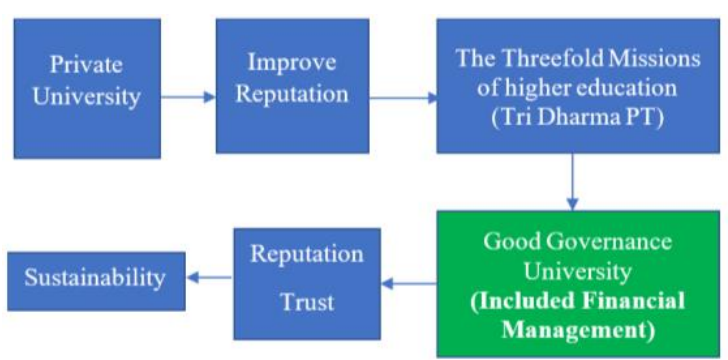

Figure 3. Framework for thinking in higher education management

\section{RESULT AND DISCUSSION}

Developing a higher education reputation is an effort that must be carried out continuously, consistently, and with hard work and refers to various regulations that have been 
made by the Government and other stakeholders. Referring to Permendikbud Number 3 of 2020, Article 42 regarding Learning Financing Standards, learning financing standards are the minimum criteria regarding the components and amounts of investment costs and operational costs that are compiled to fulfil graduate learning outcomes. Higher education investment costs are part of the cost for the provision of facilities and infrastructures, lecturer development, and educational staffing. Higher education operational costs are part of the costs needed to carry out educational activities which include lecturer fees and employee costs. The cost of operational learning materials, and indirect operational costs, is set per student per year which is called the standard unit of higher education operational costs. The higher education operational cost unit standard forms the basis for each university to prepare an annual income and expenditure budget plan and determine the costs borne by students. Under these regulations, tertiary institutions are required to have a cost recording system and carry out cost recording in accordance with the provisions of laws and regulations, conduct higher education operational cost analysis as part of the preparation of annual work plans and budgets, evaluate the level of achievement of higher education cost unit standards at each end of the fiscal year.

For private universities, administering bodies are required to seek funding from various sources outside of the tuition fees obtained from students. Other financing components outside the cost of education include grants, professional services and expertise, sustainable funds from alumni and philanthropists, and government-private institutional cooperation. Higher education institutions are required to formulate policies, mechanisms, and procedures in raising accountable and transparent sources of other funds to improve the quality of education.

Based on the above discussion, it is obtained an illustration that the sources of higher education income are expected to be varied in order to support the development of quality learning and produce reputable outcomes, both at the national and international levels. The ability to obtain operational funds and higher education development outside of student tuition fees is an achievement of a private university. This concerns negotiation skills, public trust, quality programs, a good and reliable track record, and credible management.

Referring to Figure 1 about objectives of financial management [10], it appears that a private university must focus on its vision, mission, goals, objectives, obtaining good profits for development and then become a private university that is successful with large funds for operations and endowments.

As a case study related to the application of the basic principles of financial management in the management of higher education institutions, this discussion cite Universitas Tarumanagara (Untar) as one of many higher education institutions in Indonesia. Untar in 2021 will enter the age of 62 years. Currently, Untar has 29 study programs, both undergraduate, professional, master, and doctoral, with around 15000 students. Untar has built a reputation and obtained many achievements in higher education performance, both national university rankings, international rankings through QS Rating, QR Ranking, QS E-Education Rating, performance of the threefold missions of higher education (Tri Dharma Perguruan Tinggi) such as independent research clusters, excellent community service clusters, student activity clusters, international cooperation, awards from MURI, lecturer and student exchanges, and various other reputation achievements.

To be able to achieve these various reputations and recognition, Untar has implemented a good internal quality assurance system, including quality assurance in terms of financial use through the application of basic principles of good financial management (Figure 4). Activities at Untar related to quality assurance including the quality of financial management refer to financial regulations regulated by the National Accreditation Board for Higher Education and a good financial accounting system through an external audit process by a public accountant or following an audit carried out by ISO 9001: 2015.

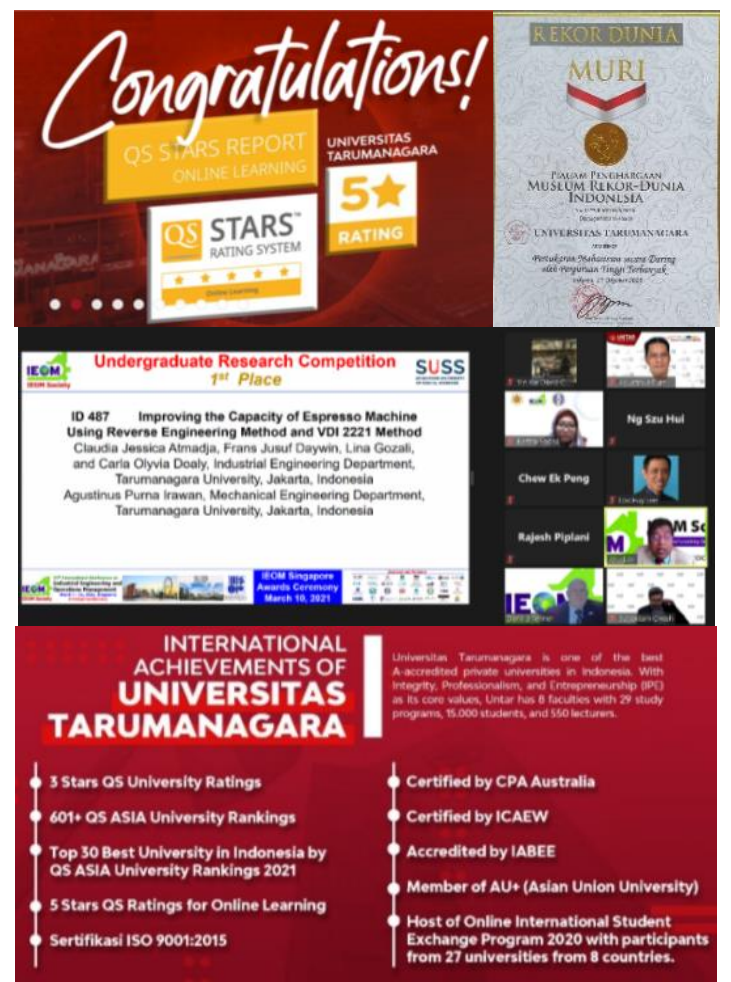

Figure 4. Some examples of recognition obtained by Untar

The following is an overview of the process carried out at Untar to develop and implement a sound financial management system in accordance with the basic principles of financial management and techniques of financial statement analysis [10] (Figure 2).

Private universities must set a priority scale in the use of finance that is owned and focused on the implementation of quality learning in which of course there are many aspects that must be considered such as the quality of lecturers, the welfare of lecturers and employees, the quality of learning facilities and infrastructure, increasing the reputation and excellence of a private university as a whole. The use of 
funds must be transparent and accountable, considering the efficiency and effectiveness of implementing various learning and development programs (Figure 5). In this case, it is especially necessary to think about and prepare for the sustainability of the program in the future, by preparing an endowment fund.

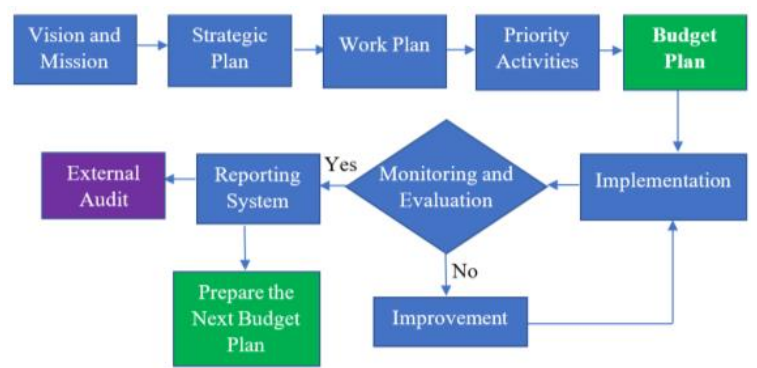

Figure 5. Business process of planning and financing activities

The model of the use of money, the reporting system and financial audits carried out at Untar can be described using a model such as Figure 6.

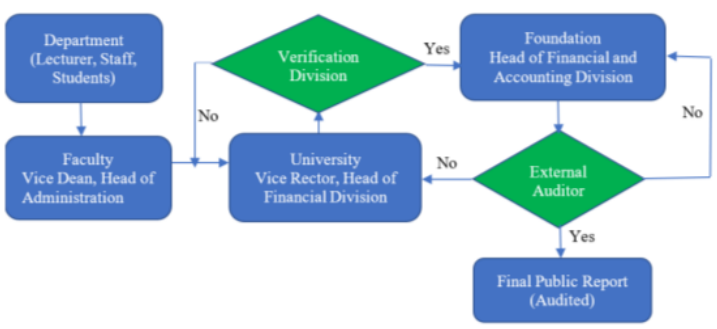

Figure 6. Flow of use of finance and audit systems

\section{CONCLUSION}

The financial management of a private university must follow the basic principles of modern financial management, which are adjusted to the university culture, the ability of students as the main source of income, reputation and performance to be achieved, and the sustainability of higher education in the future. A good financial management system implemented consistently, effectively, and efficiently, can encourage the improvement of the reputation of private universities. Higher education leaders, especially those who handle finance, must have broad insight, not only regarding how to manage finances but also how to participate in developing the reputation of private universities. A good reputation will generate the trust of the public and all stakeholders, so that they entrust their studies, research, collaborative projects, and various other activities that generate money to selected private universities. Thus, private universities can continue to develop themselves with funds that have been successfully collected from the community and gain the trust of the public, so that they can build a better reputation.

\section{REFERENCES}

[1] Peraturan Menteri Pendidikan Dan Kebudayaan Republik Indonesia Nomor 3 Tahun 2020 Tentang Standar Nasional Pendidikan Tinggi.

[2] Peraturan Badan Akreditasi Nasional Perguruan Tinggi Nomor 3 tahun 2019 tentang Instrumen Akreditasi Perguruan Tinggi, Badan Akreditasi Nasional Perguruan Tinggi Jakarta, 2019.

[3] Bunyamin Maftuh, Pedoman Pemilihan Pengelola Keuangan Berprestasi, Kementerian Ristek Dikti, 2018

[4] Mulyono. 2010. Manajemen Administrasi dan Organisasi Pendidikan. Yogjakarta: Ar Ruzz.

[5] Yuli Rifiani Joko Widodo, Kardoyo, Haryono, The Development of Financial Management Model for School-Based 9-Year Basic Education Learning Obligation in Kabupaten Kudus, The Journal of Educational Development, 4 (2) (2016), pp 175-181.

[6] Anwar Syam, D. Iwan Riswandi, 2007, Standar Akuntansi Keuangan Untuk Pengelolaan Keuangan Perguruan Tinggi Negeri Badan Hukum. Politeknik Negeri Jakarta, 2017.

[7] Anak Agung Gede Oka Wisnumurti, Tata Kelola Perguruan Tinggi Swasta Menuju Persaingan Global, Prosiding Seminar: Revitalisasi Tata Kelola Perguruan Tinggi Juni 2017 (P.1-12). Unit Penerbitan (UP) Pusat Penelitian dan Pengabdian pada Masyarakat (P3M) Unipas Singaraja. ISBN 978-979-17637-3-8).

[8] Sigit Hermawan, Heri Widodo, Analisis Model Laporan Keuangan dalam Upaya Meningkatkan Akuntabilitas Publik Pengelolaan Keuangan Perguruan Tinggi Swasta di Kabupaten Sidoarjo, Jurnal BETA, Vol 7 No. 1, 2008, pp 2-17.

[9] Harsono, Arina Hidayati, Penerapan Tata Kelola Keuangan Di Universitas Islam Batik Surakarta Untuk Mewujudkan Good University Governance, Jurnal Pendidikan Ilmu Sosial, Vol 26, No.2, Desember 2016, pp 58-74.

[10] C. Paramasivan, T. Subramanian, 2009, Financial Management, New Age International Publishers, New Delhi, India.

[11] Karen V. Pincus, David E. Stout, James E. Sorensen, Kevin D. Stocks, Raef A. Lawson, Forces for change in higher education and implications for the accounting academy, Journal of Accounting Education 40 (2017) 1-18. 
[12] Elvira Ildarovna Bulatova, Ekaterina Vladimirovna Ipatova, Financial Features of Systemically Important Banks Operation in Modern Conditions, International Journal of Financial Research, Vol. 12, No. 1; 2021, pp 23-29.

[13] Anna Polukhina, Marina Sheresheva, Marina Efremova, Oxana Suranova, Oksana Agalakova Anton Antonov-Ovseenko, The Concept of Sustainable Rural Tourism Development in the Face of COVID-19 Crisis: Evidence from Russia, Journal of Risk Financial Management, 2021, 14, 38, pp 1-19.

[14] Young-Hwan Lee, Kwon-Sik Kim and KwangHoon Lee. The Effect of Tuition Fee Constraints on Financial Management: Evidence from Korean Private Universities, Sustainability 2020, 12, 5066, pp 1-19.

[15] The UNIGOV project, Financial Management in Higher education institution, University of Alicante, May 2014. 